\title{
CARTA DE APRESENTAÇÃO
}

\section{Simpósio INTERnacional de PeSQUiSA Em AlimentaÇÃo: CIRCUITOS DE PRODUÇÃO E CONSUMO}

Nos dias 4, 5 e 6 de dezembro de 2019, ocupamos auditórios e salas de aula do prédio de História da Universidade de São Paulo com palestras, mesas-redondas e sessões de comunicação dedicadas a discutir a temática da alimentação a partir das mais diversas perspectivas, da história da fome na Idade Média às maneiras como as mídias digitais e a propaganda vêm se acercando do assunto em tempos recentes. Reunimos pesquisadores, professores e estudantes da Amazônia ao Rio Grande do Sul, passando pela Bahia, por Coiás, pelo Rio de Janeiro, por São Paulo e até mesmo por Paris e Berna, na Suíça. Trouxemos especialistas da Espanha (o antropólogo Jesús Contreras), da França (o historiador da alimentação Bruno Laurioux), dos Estados Unidos (a historiadora e curadora de museus Shirley Wajda). Montamos uma farta programação (disponível no site spalimenta.hypotheses.org), contrariando todas as tendências deste ano político de 2019, marcado por lamentáveis cortes, ou "incontingências", exatamente no setor da Educação.

Foi preciso acionar uma ampla rede de amigos, professores e colaboradores para que o simpósio se tornasse realidade nesse contexto. E aproveitamos este espaço para deixar registrado nosso sincero agradecimento aos professores que fizeram parte da organização - Henrique Soares Carneiro, Rafael de Bivar Marquese, Vânia Carneiro de Carvalho - e da Comissão Científica - além dos já citados, Carlos Alberto Dória, Janine Collaço, João Luiz Máximo da Silva, José Raimundo Sousa Ribeiro Junior, Joana Monteleone, Maria Aparecida de Menezes Borrego, Maria Henriqueta Gimenes-Minasse. Muitos destes ainda coordenaram Grupos de Trabalho, ao lado de outros colegas a quem também agradecemos imensamente: Bianca Briguglio, Cintia Cama, Isabela Rodrigues de Souza, Lucas Endrigo Avelar, Luís Fernando Teberga Conçalves, Juliana Dias, Rafaela Basso e Talita Roim.

Ao Programa de Pós-Graduação em História Social da USP, na figura do professor Marcos Napolitano, ao Departamento de História da Faculdade de Filosofia, Letras e Ciências Humanas e ao Museu Paulista da USP agradecemos pelo fundamental apoio, bem como à Coordenação de Aperfeiçoamento de Pessoal de Nível Superior (Capes), à Fundação de Amparo à Pesquisa do Estado de São Paulo (Fapesp) e ao restaurante Mocotó. Igualmente essenciais foram Claudio Rother, responsável pela identidade visual do simpósio, Ziza Pasqual, a cargo do projeto gráfico da revista Ingesta e deste Caderno de Resumos, e toda a equipe da Seção Técnica de Informática da FFLCH-USP, que nos ajudou em diversas fases da organização.

Agradecemos, ainda, aos palestrantes estrangeiros e brasileiros que, gentilmente, aceitaram nosso convite e agigantaram o simpósio: Jesús Contreras, Bruno Laurioux, Shirley Wajda, Carlos Dória, Eliane Morelli Abrahão, Gustavo Acioli, Henrique Carneiro, Leila M. Algranti, José Newton Coelho Meneses, Marle Alvarenga, Rafael Marquese e Tania Andrade Lima. Aos monitores Caio César Alves da Costa, Guilherme Rodrigues Soares, Milena Spadafora e Pedro Neves, à tradutora Silvia Makansi. E a todos que se interessaram, se inscreveram, participaram e, como já dissemos, tornaram esse simpósio uma realidade.

São Paulo, dezembro de 2019

Adriana Salay Leme, Joana Pellerano, Nicole Leite Bianchini, Viviane S. Aguiar

Comissão Organizadora 
LETTER OF PRESENTATION

II INTERNATIONAL SYMPOSIUM ON FOOD RESEARCH: PRODUCTION AND CONSUMPTION CIRCUITS

On December 4, 5 and 6, 2019, we occupied the auditoriums and classrooms of the University of São Paulo, Brazil, with lectures, roundtables, and paper sessions dedicated to discussing "food" from various perspectives, from the history of famine in the Middle Ages to the ways in which digital media and advertising have been approaching the subject in recent times. We gathered researchers, professors and students from the Amazon to Rio Grande do Sul, Bahia, Goiás, Rio de Janeiro, São Paulo and even Paris and Bern, Switzerland. We brought in specialists from Spain (food anthropologist Jesús Contreras), from France (food historian Bruno Laurioux), from the United States (historian and museum curator Shirley Wajda). We have put together a rich schedule (available at spalimenta.hypotheses.org), counteracting all the trends of this Brazilian political year of 2019, marked by lamentable cuts, or "contingencies," exactly in the education sector.

It took a wide network of friends, professors and collaborators to make the symposium a reality in this context. And we take this space to register our sincere thanks to the professors who were part of the Organizing Committee - Henrique Soares Carneiro, Rafael de Bivar Marquese, Vânia Carneiro de Carval ho and of the Scientific Committee - beyond the latter, Carlos Alberto Dória, Janine Collaço, João Luiz Máximo da Silva, José Raimundo Sousa Ribeiro Junior, Joana Monteleone, Maria Aparecida de Menezes Borrego, Maria Henriqueta Cimenes-Minasse. Many of them also coordinated the Work Groups, as well as our colleagues Bianca Briguglio, Cintia Gama, Isabela Rodrigues de Souza, Lucas Endrigo Avelar, Luís Fernando Teberga Conçalves, Juliana Dias, Rafaela Basso, and Talita Roim.

We also thank the Post-Graduation Program in Social History from USP, in the person of Marcos Napolitano, the History Department and the Museu Paulista from USP for the essential funding, as well as the Coordenação de Aperfeiçoamento de Pessoal de Nível Superior (Capes), the Fundação de Amparo à Pesquisa do Estado de São Paulo (Fapesp) and the Mocotó restaurant. Equally essentials were Claudio Rother (also from Museu Paulista), responsible for the visual identity of the symposium, Ziza Pasqual, who created the graphic project of Ingesta and of this Book of Abstracts, and the whole team of the Seção Técnica de Informática from FFLCH-USP.

We thank foreign and Brazilian lecturers: Jesús Contreras, Bruno Laurioux, Shirley Wajda, Carlos Dória, Eliane Morelli Abrahão, Gustavo Acioli, Henrique Carneiro, Leila M. Algranti, José Newton Coelho Meneses, Marle Alvarenga, Rafael Marquese, and Tania Andrade Lima; staff Caio César Alves da Costa, Guilherme Rodrigues Soares, Milena Spadafora and Pedro Neves; translator Silvia Makansi. And, finally, we thank everyone who registered, participated and, as we said, made this symposium possible.

São Paulo, December 2019

Adriana Salay Leme, Joana Pellerano, Nicole Leite Bianchini, Viviane S. Aguiar

Organizing Committee 